\title{
Regulatory framework and initiatives for realizing SDGs in achieving sustainable forest management: a comparison between Indonesia and Malaysia
}

\author{
Nasrullah ${ }^{1, *}$, Eko Priyo Purnomo ${ }^{2}$, Ahmad Zaki Salleh ${ }^{3}$, Abd Hamid bin Abd Murad ${ }^{3}$, \\ Andika Putra ${ }^{4}$, and Runi Hilda Siregar ${ }^{1}$ \\ ${ }^{1}$ Law Department, Faculty of Law, Universitas Muhammadiyah Yogyakarta, Indonesia \\ ${ }^{2}$ Government Studies, Faculty of Political Sciences, Universitas Muhammadiyah Yogyakarta, \\ Indonesia \\ ${ }^{3}$ Faculti Syariah dan Undang-Undang, Universiti Sains Islam Malaysia, Malaysia \\ ${ }^{4}$ Department of Environmental Law, Faculty of Law, Universitas Gadjah Mada, Indonesia
}

\begin{abstract}
There have been numerous literatures on sustainable forest management and its relation to sustainable development goals. However, the comparative studies on regulatory framework and initiatives for realizing Sustainable Development Goals (SDGs) and sustainable forest management remain underexplored, particularly with the recent development of legal systems and policy in Malaysia and Indonesia. This research aims to identify and compare the regulatory framework and government initiatives in Malaysia and Indonesia for the realization of SDGs with special reference to sustainable forest management by addressing deforestation and other relevant problems. The research shows that in developing the SDGs, the Indonesian government tends to overlap in formulating its regulations. The majority of initiatives built before and after implementing a sustainable forest management model in Indonesia are very much in line with what the SDGs has been aspired. The cause of the decline in forest management in Indonesia is the regulation that made beyond the realm of forest management. The vision and attempt of the Malaysian government, on the other hand, to achieve sustainable development status by 2020 are stated clearly but the results remain debateable which is similar to those of Indonesia.
\end{abstract}

\section{Introduction}

In 2020, Indonesia lost $270 \mathrm{Kha}$ of primary forest which is equivalent to 208 million tons of CO2 emissions (Graphic 1). Indonesia's forest area, which covers 64 percent of the country's total land area, is managed in three different classifications: Production Forests (Hutan Produksi, HP) cover 68.8 Mha, Conservation Forests (Hutan Konservasi, HK) cover

\footnotetext{
${ }^{*}$ Corresponding author: nasrullah@umy.ac.id
} 
22.1 Mha, and Watershed Protected Forests (Hutan Lindung, HL) comprise the remaining 29.6 Mha [1]. In 2010, Malaysia had 20.3 Mha of natural forest, over 87 percent of its land area. However, Malaysia lost $122 \mathrm{kha}$ natural forests by 2020 , equating to 85.2 million tons of CO2 (Graphic 2), Malaysia will thus have 18.27 million hectares of forest by 2021, of which 10.92 million hectares are Permanent Reserve Forests (PRF) and 3.31 million hectares are protected areas [1].

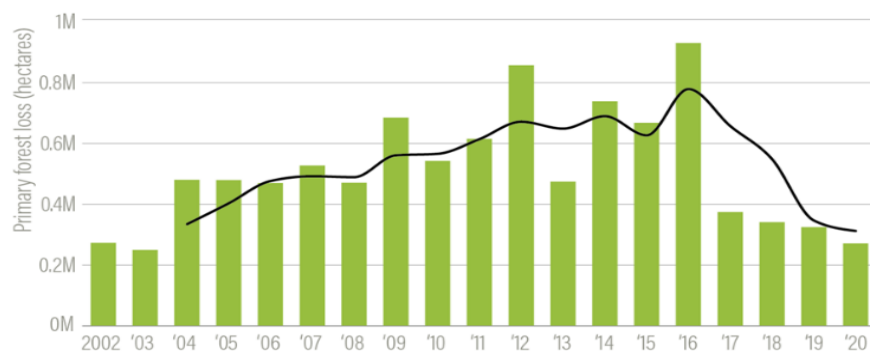

Fig. 1. Indonesia forest loss.

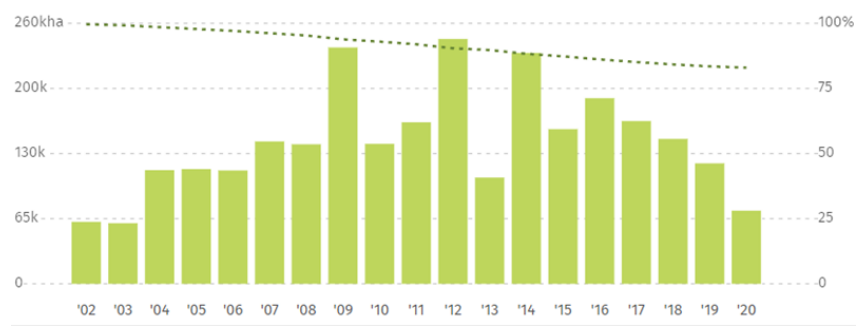

Fig. 2. Malaysia forest loss

The total forest area in both Indonesia and Malaysia has decreased from previous years due to deforestation. High rate of deforestation every year will cause the loss of forest land, which has a negative impact on the environment and social life, as the environment is central of human security which determine the sustainability of people's welfare [2].

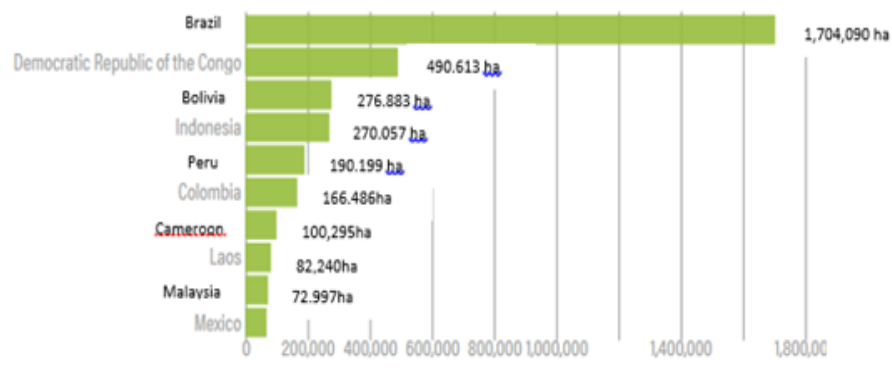

Fig. 3. Top 10 countries for 2020 primary forest loss.

Graphic 3 shows that Indonesia ranks as the $4^{\text {th }}$ of the Top 10 countries for 2020 primary forest loss with a deforestation rate of $270 \mathrm{Kha}$, while Malaysia is ranked at the $9^{\text {th }}$ 
rank [3]. The data above indicates that the trend of deforestation rate in Indonesia and Malaysia are declining. However, this does not mean the countries' deforestation problems are over. Deforestation is a hazard that comes from various sources, including forest fires, illegal logging, and other natural reasons, so the governments of Indonesia and Malaysia must continue to take preventive measures to ensure that the rate of deforestation does not accelerate.

By definition, deforestation is the loss of forest land wing to land use agreements for infrastructure, housing, agriculture, mining, and plantations [4]. Deforestation is also linked to the illegal logging, which poses a hazard to all living things and is frequently caused by forest fires, contributing to global warming [5]. According to Greenpeace, Indonesia is the third greatest emitter of carbon dioxide behind the United States and China, with forest fires accounting for about $80 \%$ of total emissions, which have a substantial impact on human health [6]. In 2021, Indonesian forest fires cover 52,481.00 ha (Directorate of PKHL, Ministry of Environment and Forestry, RI, 2021). While Malaysian forest fires cover 6000 ha [7] dropped from the previous year.

Deforestation and other causes of environmental damage raise international awareness, leading to the formation of international environmental policies that can control the behavior of countries, governments, and non-governmental organizations, allowing them to become wiser and more focused in their efforts to protect and save the environment for the sake of human survival on the planet. As a result of the Conference on Human Environment, held in Stockholm, Sweden, from June 5 to 16, 1972, culminated in the Stockholm Declaration. This trend continued until the 1992 Rio Declaration, which reiterated the 1972 Stockholm Declaration's 27 fundamental principles of sustainable development. The Rio+20 Conference's result document, the Future We Want, emphasizes the need of enhancing people's and communities' livelihoods by establishing the conditions necessary for sustainably managing forests/sustainable forest management in paragraphs 193-196 (shorten as SFM). Additionally, Chapter 11 of Agenda 21 is committed to sustaining the diverse roles and functions of all types of forests, forest lands, and woodlands.

SFM is defined as "the process of managing a forest in order to achieve one or more clearly defined management objectives, such as the production of a continuous flow of desired forest products and services without sacrificing the forest's inherent values and future productivity, and without causing undue adverse effects on the physical and social environment" [8]. In summary, sustainable forest management must strike a balance between three critical pillars: ecological, economic, and sociocultural considerations. In this regard, a wholistic approach and initiative is needed to be included in the management design [9].

In Indonesia, SFM had been mentioned in consideration of Law No. 5 of 1967 on Principal Provisions on Forestry and as a principle in Article 2 of the Law No. 41 of 1999 on Forestry, which clearly states: "The implementation of forestry is based the principles of benefits and sustainability, democracy, justice, togetherness, openness, and integration." The elucidation of that article explains that the implementation of forestry is based on benefits and is sustainable; it means that every implementation of forestry shall pay attention to the balance and sustainability of environmental, social, and cultural elements, as well as the economy. On the other hand, Malaysia has taken SFM concepts seriously in its forest development since 1971 [10].

On September 25, 2015, at the UN Headquarters, in the presence of approximately 193 heads of state, including Indonesian Vice President Jusuf Kalla, the Agenda for Sustainable Development Goals (SDGs) was officially announced [11]. The SDGs are a global action plan for the next 15 years (from 2016 to 2030) to end poverty, decrease inequality, and protect the environment. The SDGs have 17 goals and 169 targets [11], applicable to all 
signing countries. Meanwhile, Sustainable Forest Management is specified in SDG objective and target 15.2: encourage the application of sustainable forest management practices across all forest types, prevent deforestation, rehabilitate damaged forest, and significantly boost afforestation and reforestation globally.

There is now a growing number of studies to understand the issues of sustainable forest management and its relation to sustainable development goals, such as "The Timeline of Forest Management in Malaysia towards Achieving Sustainable Development Goals" [10]; "Community Forestry Projects in Malaysia: People Participation in implementing the SDGs [12]; "Forest management in Malaysia: The Strategies Undertaken towards Achieving Sustainable Development Goals" [10]; "Policy and Issues of Sustainable Natural Forest Management Certificate: Implementation of Advocacy Coalition Framework [13], and "Studi Literatur: Hutan Desa Namo sebagai Hutan Pendidikan dalam Menuju Sustainable Development Goals (SDGs) 2030 [14].

However, the comparative studies on regulatory framework and initiatives for realizing Sustainable Development Goals (SDGs) and sustainable forest management remain underexplored, particularly with the recent development of legal systems and policy in Malaysia and Indonesia. Thus, this research aims to identify and compare the regulatory framework and government initiatives in Malaysia and Indonesia in realizing SDGs with special reference to sustainable forest management by addressing deforestation and other relevant problems. This study belongs to will be normative legal research that employs some relevant approaches normally used in legal research, especially statutes and comparative approaches.

\section{Discussion}

\subsection{Regulatory framework}

\subsubsection{Constitutional position}

There is a clear distinction between Malaysia and Indonesia in terms of the state form and government system. Indonesia is a unitary republic founded on the 1945 Constitution (Undang-Undang Dasar 1945, abbreviated UUD 1945), whereas Malaysia is a constitutional monarchy based on federalism. This schism in the state affects the type of regulation in each sector, including the forestry sector.

In a unitary state, the central government exercises complete authority. As a result, there is just one state [15]; the state is constitutionally managed as a single unit with a single legislature. The state's political authority may be assigned on an independent basis to regional or local elected assemblies, governors, and mayors, but the central government retains the ultimate prerogative to revoke such delegated authority [16]. In the forestry sector, for example, the unitary system requires that all provinces, districts, and mayors in Indonesia adhere to a unified national fundamental forest strategy, as defined in Article 33 (3) of the 1945 Constitution. Due to the fact that Article 33 (3) of the 1945 Constitution vests the state (central government) with total authority over all Indonesian national resources, forest management in Indonesia is extremely centralistic in nature [17].

Although the Indonesian government is in the form of a unitary state, it is indeed aware that the form of regulation is only centralized in one command point but not a prudent thing if applied in forestry-related affairs. Considering Indonesia's geographical situation, which is divided into various islands, will make inter-island coordination difficult, so Indonesia makes every effort to change the centralized system into a decentralized one [18]. 
Therefore, the main legal framework of forestry sector management, as enacted in Law No. 41 of 1999 on Forestry, to some extend decentralized some authorities to local government.

In a federation, the federal-state power split is usually outlined in the Federal Constitution. The right to self-government of the constituent states is usually rooted in the constitution. Malaysia, under Schedule Nine of the Federal Constitution, treats land and forests as state subjects. States accept some federal government control to fulfill their commitment to the world for sustainable forest management, where one national forest policy is required, and the center should regulate forest management to achieve that policy [19].

The National Forestry Council (NFC) was founded in 1971 by the National Land Council (NLC) to encourage the adoption of a coordinated and unified approach to forestry. On April 19, 1978, the National Land Council established the Forestry Policy (which has since been replaced by the National Forestry Policy (NFP) 1992). The National Forestry Act 1984 was enacted in 1984 pursuant to Article 76(1)(b) of the Federal Constitution, and it was subsequently accepted by the 11 Peninsular Malaysian states in 1985 and 1986. Sabah and Sarawak, by contrast, retained their forestry laws and ordinances. Even in Peninsular Malaysia, despite the adoption of the National Forestry Act 1984 by each state, forest management remains independent.

Under the Ministry of Primary Industries, the Federal Forestry Department is thus reduced to a purely advisory role with little influence over resource management. As a result, forest management across states is difficult to synchronize. With each state's possession of the authority to adopt and develop their regulations, a variety of regulations are achieved but overlaps with these regulations. Uniformity in the administration of the forestry sector between states is required so that the direction of rules to be created is more concentrated and does not stray from the path originally laid out in the National Forestry Act of 1984 and the National Forestry Policy of 1978.

The preceding explanation, including its comparative structure of the constitutions of the two nations, does not imply that Malaysia is in a worse condition than Indonesia. Even though the decentralization applied by Indonesia is the safest route for a country like Indonesia, difficulties on the ground continue to be a factor impeding progress in the Indonesian forestry sector. Lack of communication between the central and regional governments may also be viewed as a hindrance, particularly when viewed through the lens of corruption and abuse of authority in practice [20]. Additionally, studies indicate that officials, political parties and members of parliament, as well as the army and police, have been involved in illegal forest activities on a direct or indirect basis [21].

\subsubsection{Regulatory Framework}

The basic legal framework for forestry sector management in Indonesia is Law No. 41 of 1999 on Forestry. In addition to this Law, Indonesia enacted the on the Prevention and Eradication of Forest Destruction in Law No. 18 of 2013 [22].

The approach taken by the Indonesian state in drafting forestry regulations may well be defined as a centralized regulation wrapped in a decentralized approach, as stated in Article 33 (3) of the 1945 Constitution, which declares that the Indonesian government has complete authority over its natural riches. However, with the revisions to the previous legislation contained in Law No. 41 of 1999, which shifted the direction of the government system from centralized to decentralized, Indonesia loosened the state of the government system to be distributed to each autonomous region, even though the ultimate power over forest management, however, still resides with the national government [23].

A centralized forest policy in a unitary state theoretically is beneficial and detrimental at the same time. It is beneficial because a centralized forest policy eases the central 
government to apply unified laws and policies nationwide in the forest sector to conserve forests and achieve sustainable forest management. On the other hand, it is detrimental because the central government usually restricts controlling and managing a large area of forests like in Indonesia. That is why it is argued that implementing effective decentralized forest governance would be more helpful for the long-term sustainable management of Indonesian forests.

Other related regulations that affect forestry in Indonesia are the Presidential Decree No. 16/2015 on the Ministry of Environment and Forestry; the Law No. 6 on Villages; the Law No. 23 of 2014 on Regional Governance; the Ministry of Forestry Decree SK.323/ Menhut-II/2011 on Suspension of Granting New Licenses and Improvement of Natural Primary Forest and Peatland Governance ("Moratorium"); the Government Regulation No 3/2008 on Forest Management Plan; the Government Regulation No. 25/2000 on Government Authority and Provincial Authority under Regional Autonomy; and the Government Regulation 34/2002 on Forest Administration and the Formulation of Plans for Forest Management, Forest Utilization, and the Use of the Forest Estate.

However, Indonesia's forestry and environmental sectors were shaken by substantial changes in 2020 due to the passage of Law No. 11 of 2020 on Jobs Creation. The legal policy of "creating work" in this law focuses solely on strengthening the economy, with less attention to Indonesia's environmental and social circumstances. The Indonesian government's efforts to streamline environmental licensing requirements for inter-local and local businesses stand in sharp contrast to the forestry industry. The existence of article 174, which gives the president complete control over the institutions under his authority including regional government, is one of the measures to simplify licensing. The regional government is one of the entities that show the existence of decentralization in Indonesia. The presence of Article 174, granting the president complete authority, demonstrates that the path followed by the Indonesian government in realizing Article 174 is the path that would eliminate the existence of a decentralized system in Indonesia shortly.

It does not stop there; the Indonesian government itself weakens the Indonesian forestry sector in paragraphs 3 of articles 21 and 22 of the job creation law. The two articles seek to withdraw previous environmental permits of local governments as the central government's authority. The pattern of separation of authority in the Job Creation Law has centralized in which the Central Government grows increasingly dominant [24]. This latest development will threaten our ability to fulfill what a nation should do to comply with the concept of SDGs, which is giving equal attention to the three main pillars of the SDGs, namely: economic growth, ecology, and social welfare.

On the other hand, Malaysia has two laws that govern its forestry sector, i.e., the National Forestry Act of 1984 and the 1992 National Forestry Policy (NFP). To ensure effective forest management in Malaysia, various forestry enactments and ordinances have been formulated and enforced by the respective State authorities since 1908. This legislation was further harmonized and strengthened in forest management planning and forest renewal operations with endorsement of the National Forestry Act and the WoodBased Industries Act in 1984. These Acts are currently being implemented by all States, particularly in Peninsular Malaysia.

The other related regulations that affect forestry for Peninsular Malaysia include the Land Conservation Act 1960; Environmental Quality Act 1974 (amended in 1985); the National Parks Act 1980 (amended in 1983); the Protection of Wildlife Act 1972 (amended in 1976 \& 1988); the National Land Code 1965; the Aboriginal Peoples Act 1954; the Occupational Safety and Health Act 1994 and the Forest Rules 1985; the Wood-based Industries Act 1984, the Water Enactment 1935; the Land Conservation Act 1960; the Malaysian Timber Industry Board Act 1973; and the Malaysian Forestry Research and Development Board Act, 1985. 
Even though 11 Peninsular Malaysian states adopted the National Forestry Act of 1984 in 1985 and 1986, Sabah and Sarawak kept their forestry laws and ordinances. For Sabah, the relevant regulations include the Forest Rules 1969; the Wildlife Conservation Enactment 1977; the Land Ordinance 1930; the Cultural Heritage (Conservation) 1997; the Sabah Parks Enactment 1984; the Biodiversity Enactment 2000; the Conservation of Environment Enactment 1996; the Water Resource Enactment 1998; and the Environmental Quality Act 1974. Meanwhile, Sarawak has the Natural Resources and Environment Ordinance 1997; the Forest Rules 1962; the Wildlife Protection Ordinance and Rules 1998; the Forests (Planted Forest) Rules 1997; the Sarawak Biodiversity Centre Ordinance 1997; the Sarawak Biodiversity (Access, Collection \& Research Regulations) 1998; the Land Code 1958; the Natural Resource and Environmental Ordinance; Water Ordinance 1994; Occupational Safety and Health Act 1994; Land Ordinance 1952; Native Code 1992; the Native Code Rules 1996, and the Native Custom Declaration 1996.

\subsubsection{Institution}

The Ministry of Environment and Forestry is the agency in the Indonesian government that oversees the forestry and environmental sectors from the very top and reports directly to the president. Previously, Indonesia had two institutions that dealt with two closely related subjects, the Ministry of Forestry and Environment. Before merging the two ministries, many things overlapped; with the merger, it is believed that the Ministry of Environment and Forestry (MEF) will be more efficient in dealing with issues concerning forests and the environment (menlhk.go.id). These institutions exist in every province of Indonesia as a vertical institution.

Compared to Indonesia, Malaysia does not have what Indonesia presently has, such as a centralized institution to deal with forestry and environmental issues. Instead, similar institutions in Malaysia are divided into three states, namely:

1. Peninsular Malaysia's Forestry Department is responsible for the management, planning, protection, and development of Permanent Reserved Forests (PRF) in accordance with the 1992 National Forestry Policy (NFP) and the 1984 National Forestry Act (NFA). (https://www.forestry.gov.my/).

2. The Sabah Forestry Department's objective are to plan and manage the State's forest resources effectively and efficiently, adhering to the principles of sustainable forest management. (http://www.forest.sabah.gov.my/).

3. Sarawak Forest Department, with the aspiration of being a world leader in sustainable forest management and the mission of managing and developing forest resources for socioeconomic and environmental sustainability (https://forestry.sarawak.gov.my/).

\subsection{Indonesia and Malaysia achievement in realizing SDGs}

Indonesia ratified the SDGs in 2016 with the promulgation of Presidential Regulation 59 of 2017 on the Implementation of Sustainable Development Goals [25]. Additionally, this Presidential Regulation demonstrates Indonesia's commitment to including all stakeholders in implementing and achieving the SDGs (Sustainable Development Goals, 2017). Unfortunately, the development of SDGs in Indonesia can be said to be slower than in Malaysia, even though Indonesia has received the average index value of SDGs realization of 66.35 in 2020 and has been ranked $97^{\text {th }}$ among 162 countries that are members of the SDGs program [26].

Meanwhile, Malaysia implemented the SDGs in 2016 by inserting them into the Eleventh Malaysia Plan (11MP) 2016-2020, which is the foundation and strategy guiding national development initiatives, demonstrating Malaysia's commitment to the SDGs 
program. Similar to how the Tenth Malaysia Plan (2011-2015) was stated to represent the government's commitment to the Millennium Development Goals, the $11 \mathrm{MP}$ is believed to reflect the multifaceted character of the Sustainable Development Goals (SDGs) [27]. As a result, in the same period, Malaysia improved the average index value from 61.7 to 69.6 in 2020; and was ranked 63rd among 162 nations that rely on the SDGs program.

However, Job Creation Law No. 11 of 2020 is the government's effort to simplify licensing in the name of the nation's economic development regardless of the tremendous impact on the environment and forestry sector. In this instance, it is reasonable to infer that Indonesia is starting to lose its orientation in the concept of the SDGs itself, with the state concentrating solely on improving the economic growth by providing 'red carpet' for the prospective investors irrespective of environmental damage and social gap as the negative impact of that policy.

\subsection{Government initiatives}

Forests are a critical component of the ecosystem and human well-being. All forest species have complex and distinct ecological processes that contribute to their current and future capabilities to provide resources for human and environmental needs. Additionally, forests are critical for economic development and the survival of all life forms. However, deforestation and forest degradation have jeopardized this unique natural resource.

Both Indonesia and Malaysia, which are recognized among tropical forest-rich countries, continue to show a solid commitment to managing and utilizing forest resources sustainably and have recently redoubled their efforts to prevent deforestation and forest degradation. Indonesia and Malaysia have enacted regulatory frameworks as preventive and punitive measures to solve these endless problems. In this regard, both states share some similarities in their legislation and implementation. Still, they differ significantly in several areas, including forest endowment and state, constitutional framework, and forest-related legislation, as previously discussed. In addition, to compare the regulatory framework, this article will also address several initiatives taken by both states. In doing so, this part will continue to address some initiatives taken by both states, namely forest fire abatement, monitoring mechanism, licensing, and certification.

\subsubsection{Forest fire abatement}

Deforestation and land clearance using the slash-and-burn method, most commonly used in Indonesia and Malaysia, is one of the most significant sources of forest fires and haze pollution in both countries [28]. Plantations, notably those producing palm oil, and the pulp and paper industry in the region stand to gain the most from the implementation of this method in their operations [29]. Practically speaking, the slash-and-burn method of clearing land is frequently recognized as the most cost-effective and efficient method of clearing land available today [27].

Deforestation and forest degradation caused by forest fires utilized in the plantation business have detrimental effects on Indonesia, Malaysia, and neighboring countries. The unavoidable consequence will manifest itself in the form of environmental damage. Greenpeace International considers the 2015 is the most severed haze pollution the twentyfirst century [30]. In 2015, Indonesian fires had burned more than 2 million hectares of forest, peatland, and agricultural land [31]. While in Malaysia, recurrent fires cause thousands of hectares of damage across the country, with most of the damage occurring on the island of Borneo. Following the onset of this problem in Indonesia and Malaysia, the source-of-origin states of fire, several measures have been implemented to put an end to 
this widespread regional problem, including the adoption of legal and non-legal measures at the national and regional levels via the Association of Southeast Asian Nations (ASEAN).

Significant forest and land fires in 2007, 2012, and 2015 have drew global attention to the Southeast Asia region, resulting in transboundary haze pollution. Both Indonesia and Malaysia have prioritized fire mitigation and response in their respective territories. In Indonesia, the project focused on enforcing the law and managing forest and land fires.

Three legal tools are being established to increase compliance and deter people or corporations responsible for forest and land fires in their concessions: administrative, civil, and criminal processes. To strengthen management and prevention, the Ministry of Environment and Forestry has increased supervision and monitoring. According to data from the Ministry of Forestry and Environment, 1,456 administrative punishments were levied between January 2015 and September 2020. 538 of those sanctions were applied in connection with forest and land fires, and administrative penalties for forest and land fires climbed considerably throughout this time period [32].

Table 1. Administrative sanctions issued to forest and land fires cases, 2015-2020 (The Ministry of Environment and Forestry, 2020, p.70)

\begin{tabular}{|c|l|c|c|c|c|c|c|c|}
\hline No & \multicolumn{1}{|c|}{ Type of sanction } & $\mathbf{2 0 1 5}$ & $\mathbf{2 0 1 6}$ & $\mathbf{2 0 1 7}$ & $\mathbf{2 0 1 8}$ & $\mathbf{2 0 1 9}$ & $\mathbf{2 0 2 0}$ & Total \\
\hline 1 & Revocation of licenses & 3 & 0 & 0 & 0 & 0 & 0 & 3 \\
\hline 2 & Suspension of licenses & 16 & 0 & 0 & 0 & 0 & 0 & 16 \\
\hline 3 & Mandatory corrective actions & 4 & 18 & 11 & 10 & 35 & 10 & 88 \\
\hline 4 & Written warnings & - & 115 & 0 & 0 & 316 & 0 & 431 \\
\hline \multicolumn{2}{|l|}{ Total } & 23 & 133 & 11 & 10 & 351 & 10 & 538 \\
\hline
\end{tabular}

In addition, from January 2015 to September 2020, the Ministry of Environment and Forestry successfully prosecuted six forest and land fire-related cases. The National Police is also investigating 82 incidents with the Ministry of Environment and Forestry. While in civil law procedure, from January 2015 to September 2020, the Ministry of Environment and Forestry filed 21 forest and land fire charges in civil court. Ten of these 21 cases have been resolved, but 11 are still pending. So far, judges have fined a total of USD 1.377 billion for environmental harm caused by fires.

Indonesian authorities have managed land and forest fires through a variety of programs and initiatives, as well as through law enforcement. The Ministry of Environment and Forestry established the Directorate of Forest and Land Fire Control (Direktorat Pengendalian Kebakaran Hutan dan Lahan) and a land fire control system known as daops manggala agni. These two agencies are tasked with the responsibility of preventing forest and land fires on a local level. Apart from that, the Indonesian government has implemented several programs and initiatives, including integrated patrols; forest and land fire prevention campaigns; weather modification technology; forest and land fire awareness and community involvement; infrastructure development for forest and land fire control; capacity development for forest and land fire management; and coordination and cooperation. These programs and activities have been implemented to address and mitigate forest and land fires in Indonesia.

In line with the Indonesian initiative, the Malaysian government had also introduced several programs to prevent and mitigate the problem of forest and land fire, with most of the fire occurring on the island of Borneo, specifically in Sabah and Sarawak. Between December 2015 and May 2016, the intensity of the El Nino phenomena had been compared to the previous extreme in 1997-1998, according to a 2016 report by the Sabah Forest Department. Around 1 million hectares (ha) of forest were destroyed during the 1982-1983 El Nino. During the 1997-1998 intense El Nino event, it was projected that around 190,00 hectares of forest were burned, while approximately 20,000 ha of forest, agriculture, and 
plantation areas were destroyed by the 2016 El Nino. Forest fire-affected areas rose dramatically in 2016 from 706 ha in 2015 [33]. In 2020, just eight forest fires were reported to the Department. The total area of forest burnt by this fire was around 556 hectares.

Table 2. Trend of Forest fire in Sabah from 2012-2020 (Sources: Sabah Forestry Department report 2016 and 2020).

\begin{tabular}{|l|l|}
\hline 2012 & 92 ha \\
\hline 2013 & 12 ha \\
\hline 2014 & 649 ha \\
\hline 2015 & 706 ha \\
\hline 2016 & 20.000 ha \\
\hline 2017 & 60 ha \\
\hline 2018 & 279 ha \\
\hline 2019 & 1.313 ha \\
\hline 2020 & 565 ha \\
\hline
\end{tabular}

The huge increase in forest fire occurrences in 2016 was mostly the result of widespread open burning by local communities and poaching to a lesser extent. Local communities took advantage of the prolonged dry spell brought forth by El Nino to conduct open burning in preparation for agricultural cultivation. Consequently, in many cases, the fires extended beyond the burn area and became wildfires, destroying forests, plantations, and farming areas. Through the Sabah Forestry Department, the government has initiated several programs and initiatives, such as forest fire early detection measures, forest fire training and awareness program, and forest fire infrastructure development.

Given the preceding narratives, both governments have undertaken various programs and policies to resolve forest and land fire issues. Both countries have experienced forest fire due to several causes; Indonesia is a major source of fire, Indonesia faces a persistent problem of open burning related to agriculture and plantation connected to palm oil and pulp \& paper. In response to this problem, the government of Indonesia's response to forest and land fires is primarily weighted toward repressive measures like fire suppression and law enforcement. However, when it comes to the core causes of forest and land fires, the limits enacted thus far have focused exclusively on land clearance by burning. Numerous additional causes have not been identified as the principal cause of forest and land fires, including land conversion, natural resource extraction, peatland use, and land conflicts. While Malaysia has also had forest and land fires on its territory, the scale of the loss was significantly less than that suffered by Indonesia, and the most of it is attributable to open burning and poaching practices by local communities. In this context, Indonesia's government activities are comparable to those in Malaysia and include a program of early detection methods for forest fires, greater public awareness, and infrastructure development.

\subsubsection{Monitoring}

Continuous or periodic surveillance of the country's prevalent forests is a necessary component of forest management practice. Regular monitoring and reporting on the forest state will result in improved prevention and response to forest management. Both Malaysia and Indonesia have initiated several monitoring mechanisms to monitor their forest.

For several decades, Malaysian forests have been monitored using a range of objectives and methodologies. It encompasses both ground and spatial surveillance and has changed through time to match current requirements. Due to Malaysia's geographical nature, distinct 
forest monitoring activities have been performed in Peninsular Malaysia and the states of Sabah and Sarawak, yet methodology and aims frequently overlapped.

The National Forest Monitoring System is organized following the country's constitutional provisions. It is composed of two parts:

a. short term - evaluation of geospatial images

b. long-term monitoring - national forest inventory

For short-term monitoring, Malaysian National Forestry Inventory started employing remote sensing in 1971 with a 1:25,000 panchromatic aerial shot. The Malaysian Remote Sensing Agency (MRSA) and Forestry Departments created the forest monitoring system to meet their demands. The system's goal is to improve forest resource monitoring, including logging. The method built has improved the monitoring program's efficiency and efficacy. It was first tried in Peninsular Malaysia in 2008 and is now being expanded to Sabah and Sarawak. The Malaysian government has performed national forest inventory starting from Peninsular Malaysia, Sabah, and Sarawak on a long-term basis.

In Indonesia, the national forest monitoring system (Simontana - NFMS) was built by the government (NFMS). The NFMS has contributed in the openness of information inside the national Climate Change Adaptation and Mitigation Monitoring, Reporting, and Verification (MRV) system. Simontana began in 2000, concentrating on remote sensing classification of forest and non-forested terrains (Landsat). Additionally, this plan will aid Indonesia in implementing its Nationally Determined Contributions and creating baselines for the national forest reference emission level (FREL). Simontana's key feature is that it makes national land cover data dating all the way back to 1990 available (Ministry of Environment and Forestry Republic of Indonesia, 2020). Along with Simontana, forest monitoring has been done through the use of integrated patrols. This 2016 endeavor yielded positive results. By 2020, integrated patrols will cover 1,200 settlements located in highrisk zones. These patrols keep an eye out for hotspots, conduct ground investigations, extinguish fires, and check for accessible water to extinguish fires. They appear to be effective for performing early reaction activities on the ground [34]. However, Indonesia's forest ranger population is insufficient to protect all forest regions. According to WWF Indonesia, Indonesia has roughly 8000 forest rangers [35]. Police officers are tasked with the responsibility of safeguarding the country's approximately 125 million hectares of forest. Police officers are spread among a number of entities, most notably the Ministry of Environment and Forestry (KLHK) and the provincial government.

\subsubsection{Certification and ecolabelling}

Certification has evolved as a critical tool in the international discussion on sustainable forest management. Malaysia's government has made efforts toward achieving 'Forest Management Certification' to improve market access and, perhaps, higher timber prices harvested from sustainably managed Permanent Reserved Forests on the international market. Malaysia currently employs two FMC programs. Malaysian Timber Certification Scheme (MTCS) is linked to the Programme for Endorsement of Forest Certification (PEFC) and the Forest Stewardship Council (FSC). The first is directly directed by the government, which developed the MTCC certification (Malaysian Criteria and Indicators, abbreviated as MC\&I), which was first guided by the International Tropical Timber Organization's (ITTO) Criteria and Indicators (C\&I). The first phase is followed by a second phase in which additional efforts are made to adhere to the FSC's Principles and Criteria (P\&C). By the end of 2020, a total of 818,965.26 hectares of Sabah's forests would have been certified under several certification systems, including the Forest Stewardship Council (FSC), the Malaysian Timber Certification Scheme (MTCS), and the Malaysian 
Standard ISO [31]. This figure grew from 2016 when 746,713.51 hectares of the State's forests were certified (Sabah Forest Department Report, 2020). Malaysia has also put its effort to meet the European Union Forest Law Enforcement, Governance and Trade (EUFLEGT) 2003 by establishing licensing scheme called Timber Legality Assurance System TLAS. Peninsular Malaysia began implementing TLAS on 1 February 2013 to assist the timber industry in meeting the due diligence standards necessary to assure timber is traded.

Indonesia, like Malaysia, has a certification framework in place through the Forest Stewards Council and the Program for the Endorsement of Forest Certification. Additionally, another trade-related mechanism has emerged in recent years that has the potential to improve forest management. The EU launched an initiative on fForest Law Enforcement, Governance, and Trade (FLEGT) in response to worldwide concerns about illegal logging and trafficking. The primary component of this strategy is the development of voluntary partnership agreements (VPAs) with nations that produce wood and wish to eliminate illegal timber from EU trade (Ahmad Maryudi, 2015). In response, the Indonesian government devised a mechanism for ensuring the legality of timber (Sistem Verifikasi Legalitas Kayu/SVLK) that is compatible with the EU-FLEGT Mechanism. The government requires V-Legal certificate documentation to export forest products under Minister of Trade Regulation No. 25/M-DAG/PER/10/2016. This legislation effectively limits the export window; only timber goods approved by V-Legal are permitted to exit Indonesia [36]. SVLK is a command-and-control system. It is a regulatory instrument that the Ministry of Environment and Forestry imposes on forest management and industry in the country (MoEF) [37].

The requirement of V-Legal has been changed over time through the Ministry of Trade Regulation No. 15 of 2020 on Export Provisions for Forestry Industrial Products; V-Legal as one of the requirements has been removed from the list of export required documents. The removal is intended to give businesses confidence and to increase forest industry exports through license simplicity. However, in response to note verbale sent by the EU delegation and negative feedbacks from several stakeholders, the government of Indonesia then enacted the Ministry of Trade Regulation No. 15 of 2020, which nullified the previous regulation which removed $\mathrm{V}$-legal as one of the requirements needed to export timber from Indonesia [38].

Both Indonesia and Malaysia place a serious concern on forest certification. Additionally, Indonesia and Malaysia have a state-based mechanism that administers national certification schemes through Sistem Verifikasi Legalitas Kayu Indonesia and Timber Legality Assurance System. In addition to that mechanism, Indonesia has also allowed certification schemes through the Forest Stewards Council and Program for the Endorsement of Forest Certification.

\subsubsection{Licensing}

As previously discussed, one of the current developments of regulation in Indonesia is the enactment of Law No. 11 of 2020 on Job Creation. This regulation has also affected license procedures on forest management. The rule pertaining to the simplification of business license refers to several legislations on the forestry sector. The major change was revising several key forestry sector rules contained in Forestry Law No. 41/1999 and Environmental Protection and Management Law No. 32 of 2009.

A notable modification in the Job Creation Law is the licensing procedure for forest areas, which is now mandatory for the use of wood forests, but not for the use of nontimber forests or environmental services. In-Law No. 41/1999 on Forestry, all sorts of permissions for the use of forest areas are detailed in the list. There are eight distinct categories of permits classified according to the forest's function and designation. 
Meanwhile, the Job Creation Law simplifies the licensing procedure to a single category, namely business license / perizinan berusaha. The effect of this law is to revoke Articles 27-29 of Law No. 41/1999, allowing for a more widespread intervention in forest areas via this business licensing scheme, and a domino effect that makes it easier for any party, particularly those with capital and power, to apply for business permits in forest areas.

Fortunately, the regulation on the moratorium of the forest is still in place. The moratorium on new forest concessions is a critical step toward states reaching their voluntary pledge to cut emissions. The moratorium on the exploitation of primary natural forests and peatlands enacted by the Indonesian government is a major policy. As a result of this approach, the Ministry of the Environment and Forestry issued a Ministerial Decree detailing a Roadmap for the Moratorium on New Forest Resource Licenses (known by the acronym PIPPIB, but more commonly referred to as the moratorium map). No new concession licenses may be granted inside the 66 million hectares, except for those already granted at the time the moratorium was proclaimed. President Joko Widodo extended the moratorium in July 2017 following its imposition in 2011 by President Instruction No. 10. It was concluded in 2019 with the publication of Presidential Instruction No. 5, which prohibited the issuing of new permits in primary forests and peatlands.

In Malaysia, logging licenses, use permits, and forest concessions are employed to combat irresponsible forest use. Forest harvesting by non-license, permission, or concession holders is prohibited and subject to penalties or damages. Although the three Malaysian states (Peninsula, Sabah, and Sarawak) have implemented this measure differently, there are still variances in the extent of licensed forest areas and the duration of forest licenses.

Unless otherwise noted, permits in the Peninsular States that have adopted the National Forestry Act may be issued for a period of 12 months. Permits are non-transferable and expire upon the present holder's death or dissolution of the body. Forest Management Units have been established on the Peninsula. Permanent Reserved Forests in each state are managed under the auspices of a ten-year forest management plan. As a result, forest management and protection are delegated to state forestry departments. District Forest Offices are charged with developing five-year and annual harvesting and silvicultural programs. Each harvesting block is granted a 12-month license to fell trees. Licenses may be subcontracted to one or more capital and equipment-equipped companies. Cutting is, however, still licensed on an annual basis in accordance with state forest management plans.

Sabah and Sarawak have established longer-term licensing schemes to distance themselves from the Peninsula. Sarawak typically grants 25 -year renewable Forest Timber Concession Agreements. They are required to develop 25-year forest management plans. Annual coupes of around 2000 ha were delineated, together with specific annual plans. It facilitated the formation of integrated harvesting and downstream processing operations that are controlled by a small number of corporate entities.

Sabah previously operated under a short-term licensing structure but now operates under 100-year Sustainable Forest Management License Agreements (SFMLAs). The SFMLAs were enacted in 1997 with the goal of encouraging licensees to develop considerable forest resources. Along with 10-year and annual work plans, licensees are required to develop fully thorough harvesting plans for each compartment. The State Forestry Department's role is to provide guidance, build capacity, and oversee the activities of SFM licensees. There have been sixteen SFM licensing agreements granted, with three being withdrawn owing to non-compliance. 


\section{Conclusions and recommendations}

There has been a backward trend toward decentralization in forest management in Indonesia as seen from Law 41/1999, and a return to centralization via Law 11/2020, specifically Article 174, which has directly or indirectly ignored one of the SDGs' pillars, namely the balance of economic and social and ecological goals. Meanwhile, Malaysia's legal framework for forest management, which is based on the federal system, remains consistent in vesting the state with complete authority. Federal government oversight is still necessary to ensure that forest management regulations continue to be directed in the direction of SFM policies, as intended by The National Forestry Law and various related regulations.

In terms of government initiatives, both Malaysia and Indonesia have addressed the issue of deforestation and forest degradation through forest fire reduction, monitoring mechanisms, licensing, and certification. Both states have some parallels in terms of their initiatives and implementation. They do, however, differ significantly in several areas, most notably in Indonesia following the enactment of Law 11/2020, which altered the forest use licensing mechanism. Additionally, only Indonesia has a moratorium policy on new forest concessions.

Acknowledgement. The research is fully sponsored by the Institute for Research, Publication, and Community Service (LP3M), Universitas Muhammadiyah Yogyakarta. The authors express their most gratitude and thanks to LP3M for granting the research grant.

\section{References}

1. S. Murniningtyas et al., The State of Indonesia's Forest 2020, Jakarta, Ministry of Environment and Forestry, Republic of Indonesia, Page. 3, (2020)

2. L. P. Karjaya, R. Satris, S. Suspiati, Greenpeace, Corporations and Deforestation Crimes: A Case study of Hongkong Shanghai Bank Corporation (HSBC) in Indonesia. Jurnal Hubungan Internasional, 8, No. 2, 203-214, (2019)

3. M. Weisse and E. Goldman, "Primary Rainforest Destruction Increased 12\% from 2019 to 2020", https://research.wri.org/gfr/forest-pulse, accessed 23 August 2021.

4. A. Yakin, "Prospek dan Tantangan Implementasi Pasar Karbon Bagi Pengurangan Emisi Deforestasi dan Degradasi Hutan di Kawasan ASEAN", Seminar Nasional “Optimalisasi Integrasi Menuju Komunitas ASEAN 2015”, Kemenlu Ri dan Universitas Mataram, Desember 2011, (2011)

5. Rimbakita, "Deforestasi - Pengertian, Penyebab, Akibat \& Cara Mencegah Penebangan Hutan”, Retrieved from https://rimbakita.com/deforestasi/ . accessed on August 5, 2021 at $02.00 \mathrm{PM},(2020)$

6. Han. E. S. et al, "Lahan dan Hutan dalam Skala Besar". Journal of Chemical Information and Modeling, 53, No. 9 1689-1699, (2019)

7. World Resources Institution. (2020). https:/bit.ly/3B0QtP1. Accessed on August 5, 2021, at $02.00 \mathrm{PM},(2020)$

8. International Tropical Timber Organization, https://www.itto.int/. Accessed on August 5, 2021, at 02.00 PM, (2020) 
9. M. Yamin, A. B. Darmawan, N. A. Zayzda, M. Ash-Shafikh, Analisis Open Government dan e-Government di Indonesia Berdasarkan Kerangka Kerja SDGs: Studi Kasus Desa Melung, Kabupaten Banyumas. Jurnal Hubungan Internasional, 7, No. 2, 133-143, (2019)

10. N Moktshim, "Forest Management in Malaysia: The Strategies Undertaken Towards Achieving Sustainable Development Goals," IOP Conference Series: Earth and Environmental Science, Orlando, Florida, (2020)

11. United Nations Development Program,. https://www.undp.org/sustainabledevelopment-goals. Accessed on August 5, 2021, at 02.00 PM, (2015)

12. D. Jayasooria, "Community Forestry Projects in Malaysia: People Participation in implementing the SDGs," UNTFSSE International Conference, Geneva, (2019)

13. Librianna et al., "Policy and Issues of Sustainable Natural Forest Management Certificate: Implementation of Advocacy Coalition Framework," Jurnal Analisis Kebijakan Kehutanan, 14, No. 2, 137-148, (2017)

14. Suprianto et al, "Studi Literatur: Hutan Desa Namo Sebagai Hutan Pendidikan Dalam Menuju Sustainable Development Goals (SDGs) 2030", Jurnal Hutan dan Masyarakat, 12, No. 2, 12-28, (2017)

15. Hariyanto, "Hubungan Kewenangan antara Pemerintah Pusat dan Pemerintah Daerah Berdasarkan Negara Kesatuan Republik Indonesia", Volkgeist 3, No. 2, 99-115, (2020)

16. M. Budiardjo, Dasar-Dasar Ilmu Politik, Jakarta: PT Gramedia Pustaka, Utama, 270271, (2002)

17. Rita Lindayati, 2002, "Ideas and Institutions in Social Foreatry Policy" in Which Way Forward? People, Forest, and Policymaking in Indonesia edited by Carol J. Pierce Colfer and Ida Aju Pradnja Resoudarmo, RFF Press, p. 37

18. M. Safitri, M. 2010. "Forest Tenure in Indonesia: The Socio-Legal Challenges of Securing Communities' Rights," Doctoral Thesis, Leiden University.

19. A. H. Ansari, "Legal Issues in Forest Management in India and Malaysia: A Critical Appraisal," The Malayan Law Journal No. 2, 21, (2004)

20. F. Downs, L. Tacconi, "A Framework to Assess The Impacts of Corruption on Forests and Prioritize Responses," Land Use Policy 60, 113-122, (2017)

21. M. Mietzner, L. Misol, "Military Businesses in Post-Suharto Indonesia: Decline, Reform and Persistence" in Rüland, J., Manea, M.G., Born, H. (Eds.), The Politics of Military Reform. Springer, Berlin, Heidelberg, 101-120, (2013)

22. M. Ali, A. Kharis, D. Karlina, "Implementasi Undang-Undang No.18 Tahun 2013 tentang Pencegahan dan Pemberantasan Perusakan Hutan (Studi Kasus Tentang FaktorFaktor yang Mempengaruhi Masyarakat Melakukan Perambahan Hutan di Desa Lunyuk Ode Kecamatan Lunyuk Kabupaten Sumbawa Besar)", Jurnal Ilmu Administrasi Publik (JIAP), 6, No. 2, 1-8, (2018).

23. A. Nasution, Government Decentralization Programs in Indonesia, ADBI Working Paper Series No. 601, Asian Development Bank Institute, (2016)

24. A. Fatanen. "Eksistensi Kewenangan Daerah Dalam Perlindungan Dan Pengelolaan Lingkungan Hidup Pasca Diterbitkannya Undang-Undang Cipta Kerja”. Khazanah Hukum, 3, No. 1, 5, (2020) 
25. Presidential Regulation Number 59 of 2017 concerning Implementation of Achieving Sustainable Development Goals.

26. J. Sachs, G. Schmidt-Traub, C. Kroll, G. Lafortune, G. Fuller, Sustainable Development Report 2019. New York: Bertelsmann Stiftung and Sustainable Development Solutions Network (SDSN), (2020)

27. F. A. Aziz, "Integrating the SDGs Into National Development Plans, Third World Network (TWN) Integrating the SDGs into National Development Plans," https://www.socialwatch.org/node/17340, (2016)

28. M. S. Islam et al., "Trans-Boundary Haze Pollution in Southeast Asia: Sustainability through Plural Environmental Governance," Sustainability, 8, No. 499, 4-6 (2016)

29. H. Varkkey, "Plantation Land Management, Fires and Haze in Southeast Asia," Malaysian Journal of Environmental Management, 12, No. 2, 35, (2011)

30. Greenpeace International, "Burning the House: How Unilever and Other Global Brands Continue to Fuel Indonesia's Fires," Greenpeace International, the Netherlands, 8, (2019)

31. The World Bank, 'the Cost of Fire: An Economic Analysis of Indonesia's 2015 Fire Crisis', Indonesia Sustainable Landscape Knowledge Note 1, 2016, p. 2. https://www.geography.org.uk/teaching-resources/singapore-malaysia/What-are-theenvironmental-impacts-of-deforestation-in-Malaysia, (2016)

32. Ministry of Environment and Forestry Republic of Indonesia, The State of Indonesia's Forest 2020, Ministry of Environment and Forestry Republic of Indonesia, 67, (2020)

33. Report Sabah Forest Department, (2016)

34. Ministry of Environment and Forestry of the Republic of Indonesia, 2020, The State of Indonesia's Forest 2020, Ministry of Environment and Forestry Republic of Indonesia, 69-70, (2020)

35. Siaran Pers WWF Indonesia, "Mendesak! Penambahan Polisi Hutan untuk Jaga Hutan Indonesia",

http://awsassets.wwf.or.id/downloads/_siaran_pers_mendesak_penambahan_polisi_h utan_untuk_jaga_hutan_indonesia.pdf.

36. A. Maryudi, "Sertifikasi (akan) Terlahir Kembali: Sisi Lain Ekspor Produk Kayu Tanpa V-Legal”, Jurnal Ilmu Kehutanan, 14, No. 1, 1, (2020)

37. A. Maryudi, Choosing Timber Legality Verification as A Policy Instrument to Combat Illegal Logging in Indonesia", Forest Policy and Economics 68, 100, (2020)

38. A. Maryudi et al., "Mandatory Legality Licensing For Exports Of Indonesian Timber Products: Balancing The Goals Of Forest Governance And Timber Industries," Forest Policy and Economics, 124, 1-3, (2021) 